Idarotuna, Vol. 1. No. 1. Oktober 2018

\title{
STRATEGI DAKWAH BERBASIS MEDIA ELEKTRONIK DI PERSATUAN MUBALIGH DUMAI (PMD) KOTA DUMAI
}

\author{
Perdamaian, Kodarni, dan Dony Arung Triantoro \\ Fakultas Dakwah dan Komunikasi UIN Suska Riau \\ Email: perdamaian@uin-suska.ac.id
}

\begin{abstract}
Abstrak
Media elektronik sebagai media dakwah masih kurang diperhatikan oleh lembaga-lembaga dakwah. Persatuan Mubaligh Dumai (PMD) sebagai salah satu lembaga dakwah yang memanfaatkan media elektronik sebagai media dakwah juga kurang optimal. Permasalahan dalam penelitian ini adalah bagaimana Strategi dakwah berbasis media elektronik di Persatuan Mubaligh Dumai (PMD) Kota Dumai. Informan penelitian ini berjumlah delapan orang. Data dikumpulkan melalui wawancara, observasi,dan dokumentasi. Dengan analisis kualitatif dapat disimpulkan bahwa strategi dakwah berbasis media elektronik di Persatuan Mubaligh Dumai (PMD) Kota Dumai yaitu; Pertama, melakukan kerjasama dengan radio ArRahman 102,2 FM, Dumai Vision dan Dumai Dokumentasi TV untuk ceramah langsung dan peliputan kegiatan PMD; Kedua, Memetakan mad'u Ketiga, melakukan kegiatan workshop, pelatihan kader, muzakarah, sertifikasi da'i dan membiasakan da'i berdakwah secara langsung di radio dan televisi dengan dibimbing oleh para pakar dakwah; Keempat, perumusan materi dakwah di media elektronik, yaitu dengan membuat tim yang ditunjuk oleh pengurus harian PMD dengan dibantu oleh para pakar dakwah serta materi dakwah yang disusun adalah materi dakwah yang sesuai dengan kebutuhan dan kondisi masyarakat; Kelima, pelaksanaan dakwah yang terkordinir, yaitu dakwah dilakukan sesuai dengan jadwal dan materi yang telah ditentukan, serta diawasi oleh Biro Pengembangan Dakwah (PMD), Kantor Urusan Agama Kota Dumai, Kementerian Agama Kota Dumai dan masyarakat.Akhirnya, bahwa strategi dakwah berbasis media elektronik di Persatuan Mubaligh Dumai (PMD) Kota Dumai sudah efektif, namun pelaksanaannya perlu dioptimalisasikan lagi.
\end{abstract}

Keywords: Strategi, Dakwah, Media Elektronik. 


\section{Pendahuluan}

Muhammad SAW adalah pelopor untuk berbuat kebaikan. Salah satu contoh praktik kebaikan yang diajarkan oleh Rasulullah SAW adalah mengajak sesama manusia untuk senantiasa berada pada jalur kebenaran. Sebagaimana disampaikan oleh Samsul Munir dalam bukunya dengan mengutip pendapat Muller mengatakan bahwa agama dakwah adalah agama yang didalamnya terdapat usaha menyebarluaskan kebenaran. ${ }^{1}$ Dakwah adalah sebuah aktivitas mulia dalam rangka menjalin hubungan baik kepada sesama manusia, hubungan baik kepada sang Khaliq, dan hubungan baik kepada alam seisinya. Allah SWT melalui Alqur'an telah menginformasikan kepada setiap hambanya untuk melaksanakan tugas mulia ini, sebagaimana tercantum dalam QS.AlImran : 104.

Ayat tersebut merupakan perintah bagi setiap hamba untuk mengajak kepada kebenaran dan kebaikan. Walaupun demikian, praktik dakwah seharusnya menjadi aktivitas pokok manusia diberbagai aspek kehidupan. Rasulullah SAW merupakan tokoh dakwah yang sangat profesional. Hal ini terbukti bahwa beliau mampu meyebarkan sebuah kebenaran dalam hal ini adalah al-din al-Islam sampai kepelosok dunia.

Sejalan dengan perkembangan zaman yang semakin modern, tentunya perhatian akan dakwah harus lebih diperhatikan. Para da'i harus selalu melakukan strategi baru untuk mensinkronisasikan antara budaya dengan metode dan budaya dengan media yang digunakan. Dengan adanya perubahan struktur sosial, strata sosial, dan kultural masyarakat yang berbasis teknologi maka tugas da'i untuk memanfaatkan media yang mutakhir dalam menyampaikan pesan dakwahnya. Tetapi sangat disayangkan banyak da'i masa kini yang tidak mampu memanfaatkan media teknologi untuk

${ }^{1}$ Samsul Munir Amin,Ilmu Dakwah, (Jakarta : Amzah, 2013), hlm. 23. mengemas pesan dakwah yang menarik. Sehingga dakwah yang dilakukannya hanya dakwah bil lisan atau dakwah dari mimbar ke mimbar.

Realita dunia dakwah saat ini menimbulkan kegelisahan karena kondisi struktur masyarakat yang sedemikian rupa, tidak sebanding dengan keahlian da'i dalam mengemas pesan dakwah. Wajar jika pesan dakwah yang disampaikan da'i tidak melekat dalam hati mad'u. Menurut penulis salah satu cara yang harus ditempuh oleh da'i adalah memanfaatkan media teknologi sebagai mediator dalam menyampaikan pesan dakwah. Media teknologi tersebut salah satunya adalah media elektronik.

PMD Kota Dumai awalnya melakukan dakwah dengan berbagai media, seperti; bulletin suara mubaligh, radio, TV Kabel dan TV live streaming. Tetapi dengan berjalannya waktu PMD hanya memanfaatkan dua media dakwah yaitu radio dan televisi. Dakwah melalui radio dan televisi di PMD kota Dumai dibuktikan dengan adanya kerjasama antara PMD kota Dumai dengan radio Ar-Rahman 102,2 FM, Dumai Vision dan Dumai Dokumentasi TV dalam bentuk siaran langsung atau live dan peliputan-peliputan kegiatan dakwah di PMD Kota Dumai.

Dakwah melalui radio dan televisi yang dilakukan oleh PMD dinilai sudah efektif tetapi belum optimal. Ini terlihat dari dampak yang dirasakan oleh masyarakat terhadap program dakwah PMD melalui media elektronik masih sekedar materi siaran dakwah biasa. Hal ini sesuai dengan observasi penulis terhadap beberapa masyarakat Kota Dumai. ${ }^{2}$ Disamping itu bahwa intensitas tayangan siaran dakwah melalui media elektronik yang dilakukan oleh PMD masih sangat rendah. Oleh karena itu perlu adanya optimalisasi dakwah melalui media radio dan televisi bagi PMD yang

\footnotetext{
${ }^{2}$ Hasil observasi dengan beberapa masyarakat Kota Dumai pada tanggal 15 Mei 2016, Pukul 16.00 WIB.
} 
diwujudkan dalam strategi dakwah berbasis media elektronik.

Jenis Penelitian ini adalah penelitian deskriptif yang mengumpulkan informasi dan membuat deskriptif tentang suatu fenomena menurut apa adanya pada saat penelitian dilakukan. Sedangkan pendekatan yang digunakan dalam penelitian ini adalah pendekatan kualitatif, yaitu suatu proses pemecahan masalah yang diteliti dengan menggambarkan objek penelitian secara rinci. $^{3}$

\section{Dakwah melalui Media Elektronik}

Media elektronik merupakan pembagian dari media massa, sebab media massa terdiri dari media cetak dan media elektronik. Hal senada juga dikatakan oleh Elvinaro Ardianto dkk bahwa media massa pada dasarnya dapat dibagi menjadi dua kategori, yakni media massa cetak dan media elektronik. Media elektronik yang memenuhi kriteria media massa adalah radio siaran, televisi, film, media online. ${ }^{4}$

Menurut Apriadi Tamburaka media elektronik adalah media massa yang menggunakan gelombang elektromagnetik yang mengubahnya menjadi audio (suara) dan visual (gambar) atau keduanya secara bersamaan. Teks, suara dan gambar yang ada itu kemudian diubah menjadi berita oleh radio dan televisi. ${ }^{5}$

Asep Saeful Muhtadi juga menambahkan bahwa pesan-pesan yang disampaikan melalui media elektronik dapat dikonsumsi oleh setiap orang, baik yang bisa melihat secara normal maupun yang tidak bisa melihat, termasuk orang yang buta huruf sekalipun. Media elektronik seperti radio dan televisi dapat dengan mudah menyapa

\footnotetext{
${ }^{3}$ Tohirin, Metode Penelitian Kualitatif, (Jakarta: Raja Grafindo Persada, 2012), hlm. 2.

${ }^{4}$ Elvinaro Ardianto dkk, Komunikasi Massa edisi Revisi, (Bandung: Simbiosa Rekatama Media, 2007), hlm. 103.

${ }^{5}$ Apriadi Tamburaka, Literasi Media, (Jakarta:Rajawali Pers, 2013), hlm. 42.
}

seorang cacat tuna netra atau sosok yang buta aksara sekalipun. ${ }^{6}$

Menurut Ahmad Atabik bahwa di era informasi seperti sekarang ini, tidak mungkin dakwah masih hanya menggunakan pengajian di mushalla dan di masjid yang hanya diikuti oleh mereka yang hadir di tempat tersebut. Penggunaan media-media komunikasi modern adalah sebuah keniscayaan yang harus dimanfaatkankeberadaannya untuk kepentingan menyampaikan ajaran-ajaran Islam atau dakwah Islam. ${ }^{7}$ Pada era sekarang ini, media elektronik dalam hal ini stasiun televisi, sangat efektif sebagai media untuk menyampaikan pesan-pesan kepada khalayak ramai. Media elektronik memiliki karakteristik yang berbeda dengan media massa lainnya.

Untuk lebih jelasnya tentang dakwah melalui media elektronik yaitu televisi dan radio maka penulis akan memaparkan teoriteori tentang dakwah melalui televisi dan dakwah melalui radio sebagaimana dibawah ini :

1) Dakwah melalui radio

Menurut Anwar Arifin bahwa radio mempunyai kelebihan yaitu banyak khalayak yang dapat dijangkau, jauh lebih luas dibandingkan surat kabar, dan meliputi seluruh lapisan masyarakat. Jadi bukan saja golongan yang terdidik atau golongan intelektual saja yang dapat mengikuti siaran radio, tetapi juga golongan yang berpendidikan rendah dan bahkan yang buta huruf pun dapat menikmatinya. Khalayak radio lebih suka siaran yang ringan-ringan saja, dan cenderung memiliki kesetiaan kepada penyiar daripada lembaganya atau stasiunnya. $^{8}$

Efektivitas dan efisiensi ini juga akan terdukung jika seorang da'i mampu

\footnotetext{
${ }^{6}$ Asep Saeful Muhtadi, Komunikasi Dakwah Teori, Pendekatan dan Aplikasi, (Bandung : Simbiosa Rekatama Media, 2012), hlm. 78.

${ }^{7}$ Ahmad Atabik, Prospek Dakwah melalui Media Televisi, dalam Jurnal Komunikasi Penyiaran Islam, Volume 1, Nomor 2,hlm. 192.

${ }^{8}$ Anwar Arifin, Dakwah Kontemporer: Sebuah Studi Komunikasi, hlm. 108-110.
} 
memodifikasi dakwah dalam metode yang cocok dengan situasi dan kondisi siaran, apakah melalui ceramah, sandiwara radio, melalui forum tanya jawab atau bentukbentuk siaran lainnya. ${ }^{9}$ Eva Maghfiroh berpendapat bahwa adapun beberapa bentuk siaran agama islam yang biasa dipakai oleh pihak radio antara lain, bentuk acara yang bersifat monologis, biasa dengan memutar kaset yang sudah direkam sebelumya atau pengajian-pengajian kitab bagi komunitas secara on air tanpa adanya interaktif. Bentuk acara yang bersifat dialogis yaitu seorang da'i menyapaikan pesan Islam secara secara langsung kepada pendengar melalui radio dan pendengar bisa ikut terlibat angsung pada acara yang sedang berlangsung dengan bertanya kepada da'i dengan cara menelfon atau SMS langsung. ${ }^{10}$

2) Dakwah melalui televisi

Menurut Muhammad Arifin bahwa televisi adalah media audio, yang juga sering disebut sebagai media pandang dengar, artinya televisi itu selain dapat kita dengar juga bisa kita lihat secara langsung. Arifin juga menambahkan bahwa alangkah besar manfaatnya jika televisi itu lebih banyak menyuguhkan siaran-siaran yang mampu merubah kondisi pemirsa dari kondisi yang tidak baik menjadi kondisi yang lebih baik. ${ }^{11}$

Di Indonesia terutama sejak awal dekade 1990-an, dunia pertelevisian ditandai dengan semakin berkembangnya TV lokal. Kehadiran TV lokal ini sekurang-kurangnya dapat menyentuh kebutuhan khalayak yang lebih dekat. Ia dapat mendekati massa sesuai warna kultural yang dianutnya. Program yang disajikan lebih mampu menyentuh watak sosiologis penontonnya. Dengan demikian, sejatinya televisi dapat memberikan pengaruh yang lebih besar. ${ }^{12}$

${ }^{9}$ Samsul Munir Amin,Ilmu Dakwah, hlm. 119.

${ }^{10}$ Eva Maghfiroh, Komunikasi Dakwah: Dakwah Interaktif Melalui Media Komunikasi, dalamJurnal Dakwah dan Komunikasi Islam, Volume 2, Nomor 1, hlm. 47.

${ }^{11}$ Muhammad Arifin, Dakwah Multi Media:Terobosan baru Bagi Para Da'i, (Surabaya: Graha Ilmu Mulia, 2006), hlm. 77.

${ }^{12}$ Asep Saeful Muhtadi, Komunikasi Dakwah Teori, Pendekatan dan Aplikasi, hlm. 88.
Menurut Toni Hartono dkk, bahwa televisi sangat penting untuk menjadi media dakwah atau menyalurkan pesan-pesan dakwah. Hal ini banyak dilakukan di Indonesia. Pada umumnya media televisi menyediakan waktu untuk kegiatan dakwah tidak hanya pada program sinetron seperti adzan magribh atau acara-acara khusus pada bulan ramadhan, hari-hari besar Islam,dan sebagainya. Televisi juga dapat menjadi sarana untuk menanggapi keluhan dan permasalahan-permasalahan yang dihadapi umat Islam melalui dialogis keagamaan. ${ }^{13}$

Ahmad Atabik juga mengatakan hal yang sama bahwa di beberapa daerah di negeri ini masyarakat banyak menghabiskan waktunya untuk melihat televisi. Kalau dakwah Islam dapat memanfaatkan media ini dengan efektif, maka secara otomatis jangkauan dakwah akan lebih luas dan kesan keagamaan yang ditimbulkan akan lebih dalam. $^{14}$

Seorang da'i yang tampil didepan kamera TV haruslah menyesuaikan diri dengan karakteristik kamera serta peralatan lain yang menopang suatu produksi audio visual, seperti cahaya yang tersorot kewajahnya. Ketidakbiasaan berbicara di depan kamera peralatan studio yang canggih dapat membuat seorang da'i menjadi kikuk. Kekakuan di hadapan kamera membawa dampak tegang dan tidak santai yang berakibat arus pesan komunikasi dakwah yang disampaikan menjadi tersendat-sendat. Da'i yang tampil di depan kamera seyogianya tidak menggunakan naskah. Bagi da'i yang berdakwah di depan kamera televisi, selainmengendalikan fleksibilitas suaranya, tidak kalah penting ialah faktor bahasa tubuh, ekspresi wajah dan gerak gerik anggota tangannya. Da'i seyogianya mampu mempersembahkan pribadi yang menyenangkan, suara yang menarik, suara dan wajah yang serasi. Dalam hal ini

\footnotetext{
${ }^{13}$ Toni Hartono dkk, Komunikasi Dakwah,(Pekanbaru: Yayasan Pustaka Riau, 2011), hlm. 137.

${ }^{14}$ Ahmad Atabik, Prospek Dakwah melalui Media Televisi, dalam Jurnal Komunikasi Penyiaran Islam, Volume 1, Nomor 2, hlm. 195.
} 
diperlukan persiapan yang matang bagi da'i untuk melakukan apresiasi dan improvisasi dalam melakukan dakwah di media elektronik. $^{15}$

Berdasarkan beberapa pendapat diatas, maka dapat penulis simpulkan bahwa media elektronik adalah media yang cukup berpengaruh dalam penyebaran dakwah di era modren ini. Dengan media elektronik maka mad'u dapat mengakses segala informasi terkait dakwah dengan cepat dan praktis. Media elektronik yang saat ini digandrungi oleh masyarakat adalah radio dan televisi, sehingga media ini sangat memberikan dampak yang besar dalam mengubah pemahaman agama mad'u. Media radio dan televisi dapat diakses oleh kalangan bawah, menengah dan atas, tua dan muda, berpendidikan ataupun tidak.

Pemanfaatan media elektronik yaitu radio dan televisi dalam aktivitas dakwah bukanlah semudah yang kita bayangkan, akan tetapi seorang da'i/komunikator dituntut mampu membuat strategi baru dalam aktivitas dakwahnya di media elektronik. Hal ini disebabkan karena karakteristik media elektronik antara satu dengan yang lainnya berbeda-beda.

\section{Hasil Penelitian}

Strategi dalam berdakwah menjadi hal yang sangat penting di era ini, terutama menjadikan dakwah sebagai upaya mentransformasi nilai-nilai kebaikan. Karena itu, dakwah hendaklah dilakukan secara profesional, dinamis, dan fleksibel. Serta dakwah juga harus disesuaikan dengan perkembangan teknologi kekinian seperti televisi dan radio.Berdasarkan hal tersebut maka lembaga dakwah pada umumnya harus mampu mengkonsep dakwah melalui media elektronik dengan strategi-strategi tertentu. Jika dakwah melalui media elektronik dilakukan dengan pendekatan strategi tertentu, maka tidak dipungkiri peluang keberhasilan dakwah di era teknologi ini juga akan semakin besar.

\footnotetext{
${ }^{15}$ Samsul Munir Amin, Ilmu Dakwah, hlm. 272-273.
}

Strategi dakwah berbasis media elektronik di PMD Kota Dumai berdasarkan hasil wawancara pada tanggal 27 Desember 2016 sampai dengan 3 Januari 2017 adalah sebagai berikut :

\section{Kerjasama dengan Media Televisi dan Radio tertentu \\ PMD \\ Kota \\ Dumaidalam}

menyampaikan misi dakwahnya juga tidak meninggalkan media-media penyiaran yang ada. Sebab dengan mengajak media-media penyiaran tertentu dalam melakukan transformasi nilai-nilai dakwah kepada masyarakat akan mempermudah lembaga dakwah itu sendiri. Atas dasar itu maka PMD Kota Dumaimelakukan kerjasama dengan berbagai media penyiaran tertentu seperti Dumai Dokumentasi TV, Dumai Vision dan Radio Ar-Rahman 102,2 FM. Sebagaimana disampaikan oleh beberapa pengurusPMD Kota Dumai dalam hasil wawancara sebelumnya.

Menanggapi penjelasan dari pengurus PMD Kota Dumai sebelumnya, menurut penulis bahwa PMD Kota Dumai telah melakukan pemanfaatan media elektonik sebagai media dakwah. Penyampaian dakwah melalui media elektronik seperti radio dan televisi akan lebih efektif dan efisien. Hal ini juga sesuai pendapat Samsul Munir Amin dalam bukunya yang mengatakan bahwa Penggunaan radio dalam aktivitas dakwah sangatlah efektif dan efisien. Melalui radio, suara dapat dipancarkan ke berbagai daerah yang jaraknya tidak terbatas. Jika dakwah dilakukan melalui siaran radio dia akan mudah dan praktis, dengan demikian dakwah akan mampu menjangkau jarak komunikan yang jauh dan tersebar. ${ }^{16}$

Pemanfaatan media elektronik sebagai media dakwah tentunya harus disertai dengan sistem yang terencana. PMD Kota Dumai mempunyai sistem kerjasama dengan radio Ar-Rahman 102,2 FM, Dumai Vision dan Dumai Dokumentasi TV. Sistem penyampaian dakwah di radio Ar-Rahman

\footnotetext{
${ }^{16}$ Samsul Munir Amin, Rekontruksi Pemikiran Dakwah Islam, hlm. 190.
} 
102,2 FM dilakukan dengan dakwah secara langsung atau live berdasarkan jadwal yang telah ditetapkan dan program-program dari pihak radio seperti, selamat pagi ar-Rahman, tausyiah kehidupan, kisah-kisah teladan, hikmah hadits pilihan dan sebagainya.

Sistem penyampaian dakwah melalui Dumai Vision juga dilakukan dengan dakwah secara live di studio Dumai Vision berdasarkan undangan dari pihak TV pada hari-hari besar Islam seperti, maulid nabi, isra' mi'raj, tahun baru hijriyah, kultum menjelang berbuka puasa pada bulan ramadhan dan hari-hari besar nasional lainnya. Sedangkan sistem penyampaian dakwah melalui Dumai dokumentasi TV dilakukan melalui peliputan-peliputan kegiatan dakwah PMD Kota Dumai, seperti pelatihan kader da'i, sertifikasi da'i, workshop, muzakarah dan lain sebagainya. Hal ini sesuai dengan hasil wawancara dengan beberapa pengurus PMD Kota Dumai sebelumnya dan observasi penulis melalui website Dumai dokumentasi TV.

Menanggapi pernyataan pengurus PMD Kota Dumai dalam hasil wawancara sebelumnya, menurut penulis bahwa PMD Kota Dumaitelah melakukan persiapan dakwah yang matang melalui media elektronik. Persiapan-persiapan itu dibuktikan dengan adanya sistem kerjasama yang telah disepakati sebelumnya.

Salah satu sistem kerjasama yang dilakukan oleh PMD Kota Dumai dengan radio Ar-Rahman adalah dalam bentuk dakwah secara live di radio dengan metode Tanya jawab. Hal ini sesuai dengan pendapat Samsul dalam bukunya yang mengatakan bahwa dakwah melalui radio dapat juga dikemas dalam bentuk acara yang bersifat dialogis (berbincang-bincang) ada juga yang bersifat monologis (seorang da'i sendirian tampil di corong radio). ${ }^{17}$

Sedangkan sistem dakwah melalui Dumai vision yang dilakukan oleh PMD Kota Dumai adalah dalam bentuk ceramah langsung di studio Dumai vision. Melalui

\footnotetext{
${ }^{17}$ Samsul Munir Amin, Rekontruksi Pemikiran Dakwah Islam, hlm. 190.
}

televisi seorang pemirsa dapat mengikuti kegiatan dakwah seakan dia berada langsung dihadapan da'i dan bahkan sekarang sudah banyak siaran langsung yang dilakukan untuk kepentingan siaran dakwah. ${ }^{18}$

Berdasarkan penjelasan diatas, menurut penulis PMD Kota Dumai telah melakukan langkah yang tepat dalam menyebarkan dakwah melalui media elektronik. Sebab dengan bekerjasama melalui lembaga penyiaran seperti radio ArRahman 102,2 FM, Dumai Dokumentasi TV dan Dumai Vision maka pesan dakwah dapat disampaikan secara cepat dan menyeluruh. Sebagaimana sifat dari radio seperti yang dijelaskan oleh Muhammad Anwar Arifin dalam bukunya bahwa radio mempunyai kelebihan yaitu banyak khalayak yang dapat dijangkau, jauh lebih luas dibandingkan surat kabar, dan meliputi seluruh lapisan masyarakat. ${ }^{19}$ Sedangkan Samsul Munir Amin juga menjelaskan tentang kelebihan televisi bahwa televisi juga sangat efektif untuk digunakan sebagai media penyampai pesan-pesan dakwah karena kemampuannya yang dapat menjangkau daerah sangat luas. ${ }^{20}$

Disamping itu, menurut penulis bahwa saat ini PMD Kota Dumai belum memiliki Lembaga penyiaran tersendiri, sehingga sangat perlu untuk menjalin kerjasama yang baik dengan lembaga-lembaga penyiaran tersebut.

Dewasa ini perkembangan zaman telah memaksa manusia untuk mensinergikan antara kemampuan dengan teknologi dan antara pijakan teori spiritual dengan teori sains dan teknologi. Begitu juga dalam dunia keorganisasian dan kelembagaan, termasuk lembaga dakwah itu sendiri. PMD Kota Dumai merupakan lembaga dakwah yang sudah berusaha memulai mensinergikan antara aspek spiritualitas dengan aspek sains dan teknologi. Hal ini dibuktikan melalui kerjasama-kerjasama dengan lembaga

\footnotetext{
${ }^{18}$ Samsul Munir Amin, Ilmu Dakwah, hlm. 120-121.

${ }^{19}$ Anwar Arifin, Dakwah Kontemporer: Sebuah Studi Komunikasi, hlm. 108-109.

${ }^{20}$ Samsul Munir Amin, Ilmu Dakwah, hlm. 120-121.
} 
penyiaran diatas. Maka menurut penulis, bahwa kerjasama tersebut adalah kerjasama yang akan memudahkan pesan dakwah dapat diterima oleh masyarakat informasi pada saat sekarang ini.

\section{Pemetaan Mad'u di Media Elektronik}

Melakukan peninjauan terhadap siapa yang menjadi penerima dakwah (mad'u) di media elektronik adalah menjadi suatu keharusan yang harus dilakukan oleh lembaga dakwah, agar pesan dakwah yang disampaikan dapat diterima dengan baik oleh mad'u. Hal ini sesuai dengan yang disampaikan oleh Kustadi Suhandang dalam bukunya bahwa dalam melakukan strategi perlu adanya pengenalan terhadap kondisi khalayak (mad'u). ${ }^{21}$

PMD Kota Dumai dalam melakukan dakwahnya melalui radio Ar-Rahman 102,2 FM, Dumai Dokumentasi TV dan Dumai Vision difokuskan pada wilayah tertentu. Dakwah melalui radio Ar-Rahman 102,2 FM difokuskan kepada masyarakat Kota Dumai yang terdiri dari tujuh kecamatan, diantaranya yaitu Kec.Dumai Timur, Kec.Dumai Barat, Kec.Dumai Selatan, Kec. Dumai Kota, Kec.Medang Kampai, Kec.Sungai Sembilan dan Kec.Bukit Kapur.

Pemfokusan ini dilakukan berdasarkan jangkauan radio itu sendiri. Sedangkan objek dakwah melalui Dumai Vision difokuskan kepada Seluruh masyarakat Kota Dumai yang memakai jasa siaran TV Kabel yaitu Dumai Vision. Dumai vision adalah salah satu jasa TV kabel di Kota Dumai yang diminati oleh masyarakat. Hal ini sesuai hasil observasi yang penulis lakukan di tujuh kecamatan tersebut dengan beberapa orang masyarakat yang mendengarkan siaran radio Ar-Rahman 102,2 FM dan Dumai Vision.

Berbeda pula dengan objek dakwah melalui Dumai Dokumentasi TV yaitu seluruh masyarakat yang memiliki akses jaringan internet didalam maupun diluar Kota Dumai baik anak-anak, remaja dan dewasa. Dumai Dokumentasi TV adalah TV online atau Live Streaming yang ada di kota

\footnotetext{
${ }^{21}$ Kustadi Suhandang, Strategi Dakwah Penerapan Strategi Komunikasi dalam Dakwah,105106.
}

Dumai yang mudah diakses oleh masyarakat pengguna Internet. Hal ini sesuai hasil wawancara dengan beberapa pengurus PMD Kota Dumai sebelumnya dan observasi terhadap situs Dumai Dokumentasi TV.

Dewasa ini, menurut penulis bahwa keinginan masyarakat untuk mengakses radio dan televisi yang bermuatan nilai-nilai Islam sangat kecil sekali. Sehingga objek dakwah melalui radio dan televisi hanyalah bagi mereka yang peduli terhadap media itu sendiri. Hal ini sesuai yang disampaikan oleh Sekretaris Umum PMD Kota Dumai dalam hasil wawancara sebelumnya.

Berdasarkan penjelasan diatas, maka penulis dapat menyimpulkan bahwa PMD Kota Dumaitelah melakukan proses identifikasi terhadap wilayah mana saja yang menjadi objek dakwahnya melalui radio dan televisi. Dengan adanya identifikasi tersebut maka PMD Kota Dumai dapat mengetahui materi dakwah seperti apa yang sesuai dengan struktur dan kondisi mad'unya.

Pemetaan mad'u dalam dakwah melalui radio dan televisi menjadi suatu keharusan yang harus dilakukan oleh lembaga dakwah. Keberhasilan dakwah sangat berpengaruh signifikan terhadap kemampuan da'i atau lembaga dakwah untuk memahami psikologi, budaya dan latar belakang mad'unya. Hal ini sesuai dengan yang dikatakan oleh Kustadi Suhandang dalam bukunya bahwa dalam melakukan persiapan dakwah perlu adanya pengenalan terhadap khalayak sasaran (mad'u) melalui identifikasi terhadap jumlah dan lokasi dimana mad'u berada. Kustadi juga menambahkan bahwa dalam pelaksaan strategi diperlukan persiapan yaitu salah satunya segmentasi khalayak sasaran $(\operatorname{mad} u){ }^{22}$

Maka menurut penulis bahwa langkah yang dilakukan oleh PMD Kota Dumai dalam membuat pemetaan wilayah-wilayah yang menjadi objek dakwahnya melalui media radio dan televisi adalah sangat tepat.

\footnotetext{
${ }^{22}$ Kustadi Suhandang, Strategi Dakwah Penerapan Strategi Komunikasi dalam Dakwah, hlm. 105-106.
} 
Menanggapi apa yang disampaikan oleh Ketua PMD Kota Dumaidalam hasil wawancara sebelumnya, bahwa ketujuh kecamatan yang menjadi objek dakwah di radio merupakan kecamatan yang terjangkau dengan frekuensi radio tersebut. Sedangkan menurut penulis tentang objek dakwah PMD Kota Dumai melalui Dumai Vision yang dikhususkan kepada pengguna jasa TV Kabel Dumai vision juga dinilai tepat, sebab tidak semua masyarakat Kota Dumai yang menggunakan jasa TV Kabel tersebut.

Berbeda pula dengan objek dakwah PMD Kota Dumai melalui Dumai Dokumentasi TV yang lebih luas. Dikatakan luas karena Dumai Dokumentasi TV merupakan TV online atau Live Streaming yang dapat diakses oleh pengguna internet dimanapun berada. Tanggapan masyarakat terhadap dakwah melalui media elektronik sangat baik, responsif dan mendukung. Hal ini sesuai dengan yang disampaikan oleh beberapa pengurus PMD Kota Dumai dalam hasil wawancara sebelumnya.

Jika dakwah dikolaborasikan dengan perkembangan teknologi yang ada maka akan memberikan semangat baru ditengahtengah masyarakat. Sebab dakwah yang tidak mampu mengimbangi perkembangan teknologi akan ditelan oleh zaman. Hal ini sesuai dengan pendapat Samsul nya bahwa dalam era globalisasi dan era informasi diperlukan penerapan dakwah yang dapat menjangkau dan mengimbangi kemajuankemajuan tersebut, ${ }^{23}$ sehingga kehadiran PMD Kota Dumai dalam membawa konsep dakwah berbasis media elektronik disambut baik oleh masyarakat. Sebagaimana disampaikan oleh Sekretaris Umum PMD Kota Dumai dalam hasil wawancara sebelumnya.

\section{Persiapan Da'i berbasis Elektronik}

Sejalan dengan perkembangan zaman yang semakin modern dengan berbagai kemajuan teknologi yang ada, tentunya mengakibatkan lembaga-lembaga maupun intansi untuk melakukan peningkatan sumber

\footnotetext{
${ }^{23}$ Samsul Munir Amin,Ilmu Dakwah, hlm. 111.
}

daya manusia berbasis teknologi. Hal ini dilakukan agar lembaga senantiasa mampu beradaptasi dengan perubahan dan perkembangan zaman.

Begitu pula dengan PMD Kota Dumai yang senantiasa melakukan follow up untuk mengembangkan sumber daya da'i yang ada. Pengembangan itu bukan hanya dalam tatanan materi dakwah yang harus relevan dengan perkembangan zaman, tetapi juga harus mengembangkan media dakwah yang ada. Hal ini sesuai pendapat Samsul dalam bukunya bahwa aktivitas dakwah Islam saat ini tidak cukup dengan menggunakan mediamedia tradisional, seperti ceramah-ceramah dan pengajian-pengajian yang masih menggunakan media komunikasi oral atau komunikasi tutur. Penggunaan media-media komunikasi modern sesuai dengan taraf perkembangan daya pikir manusia harus dimanfaatkan sedemikian rupa agar dakwah Islam lebih mengena sasaran dan tidak out of date. $^{24}$

PMD Kota Dumai sebagai lembaga telah mempersiapkan da'i-da'i berbasis elektronik yang akan diterjunkan ke mediamedia yang ada. Upaya-upaya yang dilakukan oleh PMD Kota Dumai dalam mempersiapkan da'i-da'i berbasis elektronik diantaranya dengan membuat workshop pemanfaatan media dalam dakwah dan pelatihan kader da'i bersama IAI Tafaqquhfiddin Dumai. Pelatihan bagi para da'i tersebut akan menjadi faktor pendukung keberhasilan dakwah di radio dan televisi. Da'i di PMD Kota Dumai dilatih untuk mengembangkan kemampuan dakwahnya. Setiap da'i diberikan pelatihan secara intensif oleh para da'i senior dan para mentor yang didatangkan dari lembaga perguruan tinggi yaitu UIN Sultan Syarif Kasim Riau dan IAIN Imam Bonjol Padang.

Secara praktis mubaligh PMD Kota Dumai dibiasakan terjun langsung untuk berdakwah di radio dan televisi sehingga hal ini menjadi proses latihan bagi para mubaligh di PMD Kota Dumai. Tidak hanya pelatihan pemanfaatan media dalam dakwah,

\footnotetext{
${ }^{24}$ Samsul Munir Amin,Ilmu Dakwah, hlm. 112
} 
pelatihan kader da'i, sertifikasi da'i dan membiasakan mubaligh berdakwah secara langsung di radio dan televisi saja, tetapi juga dalam bentuk tabligh akbar bersama ustad-ustad yang menguasai banyak media, seperti Ustad Wijayanto dari Jakarta.

Berdasarkan hasil wawancara sebelumnya, penulis menyimpulkan bahwa PMD Kota Dumai telah melakukan persiapan da'i berbasis media elektronik, hal ini dibuktikan dengan adanya pelatihan atau workshop bagi para mubaligh melalui dokumentasi-dokumentasi yang penulis observasi. Disamping dengan adanya pendalaman materi berbasis media yang dikemas dalam bentuk pelatihan maupun workshop. Hal ini sesuai dengan yang disampaikan oleh Anwar Arifin bahwa salah satu langkah-langkah strategis yang harus dirumuskan dalam melakukan dakwah adalah tersedianya komunikator dakwah dan organisasi dakwah yang terpercaya. ${ }^{25} \mathrm{Hal}$ tersebut telah dilakukan oleh PMD Kota Dumai dalam menyiapkan komunikator dakwah melalui pelatihan-pelatihan. Seorang mubaligh mampu menjalankan tugasnya dengan baik dan tercapai tujuan dakwahnya jika mubaligh dibiasakan melakukan kegiatan dakwah secara praktis di tengah masyarakat.

Pelatihan atau workshop dan kebiasaan melakukan dakwah secara langsung di radio dan televisi memang mempengaruhi keprofesionalitasan da'i dalam dakwahnya di radio dan televisi. Akan tetapi ada faktor pendukung lain yang sangat berperan dalam menentukan keprofesionalitasan da'i dalam dakwahnya di radio dan televisi yaitu peran mentor dalam melakukan pelatihan.

PMD Kota Dumai sebagai lembaga yang telah melakukan pelatihan pemanfaatan media dalam dakwah bagi para da'i juga selektif dalam memilih mentor. Mentormentor yang memberikan pelatihan itu adalah para pakar yang berasal dari Lembaga Peningkatan dan Pengembangan Dakwah (LPPD) Fakultas Dakwah dan Komunikasi

\footnotetext{
${ }^{25}$ Anwar Arifin, Dakwah Kontemporer Sebuah Studi Komunikasi, hlm. 233.
}

IAIN Imam Bonjol Padang dan UIN Sultan Syarif Kasim Riau.

Menurut penulis dengan mendatangkannya para mentor dari berbagai Perguruan Tinggi maka hal ini akan memberikan penyegaran bagi para da'i dalam pemantaban keilmuan dakwah yang dimilikinya, terutama kemampuan dakwah melalui media elektronik. Disamping itu bahwa pelatihan akan memberikan hasil yang maksimal jika disertai dengan para mentor yang berkredibilitas tinggi dan kesiapan da'i untuk mengikuti pelatihan tersebut.

Tidak hanya Pelatihan dan kegiatan tabligh akbar saja yang dilakukan PMD Kota Dumai dalam mempersiapkan da'i berbasis elektronik, tetapi juga upaya-upaya lain yang dilakukan seperti, muzakarah, peningkatan jenjang pendidikan da'i, sertifikasi da'i dan sebagainya. Hal ini diungkapkan oleh Ketua Umum PMD Kota Dumai dan Sekretaris Umum PMD Kota Dumai serta dibenarkan oleh Biro Pengembangan Dakwah Persatuan PMD Kota Dumai. Berdasarkan hasil wawancara sebelumnya, PMD Kota Dumai mengutamakan kualitas para da'inya. Ini terbukti dengan dilakukannya muzakarah dalam rangka pemantapan materi dakwah dan sertifikasi da'i yang akan menentukan lokasi dakwahnya. Adanya sertifikasi ini maka da'i termotivasi untuk memperbaiki kemampuan dakwahnya, termasuk dakwah di media elektronik.

\section{Perumusan Materi Dakwah di Media Elektronik}

Materi dakwah merupakan salah satu elemen dakwah yang perlu diperhatikan. Pesan atau materi dakwah hendaknya dapat merangsang objek dakwah untuk mengamalkan secara mendalam tentang nilai-nilai Islam. Materi dakwah harus dilakukan dengan mempertimbangkan situasi dan kondisi mad'u serta membahaskondisi yang sedang terjadi ditengah-tengah masyarakat atau isu-isu terkini.

PMD Kota Dumai senantiasa mempersiapkan materi-materi dakwah yang sesuai kondisi sosial masyarakat, seperti mewaspadai aliran sesat, pentingnya 
menjaga lingkungan, peran pemuda dan pembangunan, perdagangan (bisnis) secara Islam, persepsi Islam terhadap sains dan teknologi, kisah-kisah teladan yang membahas tentang perjalanan hidup Rasulullah SAW dan sahabatnya, hikmah Hadits yang membahas tentang ilmu-ilmu hadits dan makna suatu hadits tertentu. Materi-materi itu merupakan materi yang sesuai dengan kebutuhan mad'u di kota. Perumusan materi dakwah di media elektronik dilakukan oleh tim penyusun materi dakwah yang ditunjuk oleh pengurus harian PMD Kota Dumai dan dibantu oleh para pakar dakwah, seperti Ust.H.Abdul somad, Lc.MA, Dr.H.Mawardi M.Saleh, MA, dan sebagainya. Hasil dari penyusunan itulah yang akan menjadi panduan da'i dalam dakwahnya di masjid, mushola dan media.

Menanggapi penjelasan beberapa PMD

Kota Dumai dalam hasil wawancara sebelumnya, menurut penulis penyeleksian terhadap materi dakwah oleh para pakar dakwah seperti, Ust.H.Abdul Somad, Lc.,MA, dan Ust.Dr.H.Mawardi M. Saleh, MA akan menghasilkan konsep-konsep dakwah yang menarik dan bermutu. Hal ini disebabkan karena mereka adalah da'i-da'i yang mapan dalam keilmuan agama. Penyeleksian itu merupakan usaha PMD Kota Dumai untuk bisa merangsang objek dakwah dalam mengamalkan nilai-nilai islam yang disampaikan melalui media elektronik. Disamping itu, bahwa materi yang diangkat oleh PMD Kota Dumai adalah seputar isuisu keagamaan yang sedang berkembang ditengah-tengah masyarakat dan sesuai dengan kondisi mad'u,sehingga menurut penulis pemilihan materi tersebut akan membuat mad'u tertarik untuk mendengarkan dakwah-dakwah PMD Kota Dumai melalui media elektronik dan sebagainya.

Hal ini sesuai dengan pendapat Samsul Munir Amin yang mengatakan bahwa materi dakwah harus disampaikan secara menarik sehingga merangsang objek dakwah untuk mengkajinya. Pesan-pesan dakwah disampaikan dengan mempertimbangkan situasi dan kondisi mad'u sebagai penerima dakwah. ${ }^{26}$ Ini merupakan strategi PMD Kota Dumai yang telah disiapkan untuk mencapai kesuksesan visi dan misi dakwahnya di radio dan televisi. Kustadi Suhandang juga menjelaskan bahwa dalam melakukan strategi dakwah perlu adanya persiapanpersiapan. Salah satunya adalah persiapan penyusunan rencana dan pesan yang akan disampaikan juga pengenalan terhadap pengetahuan, sikap, kegiatan mad'u seharihari dan deskripsi sikap terhadap hal-hal yang disenangi dan tidak disenangi mad'u. ${ }^{27}$

\section{Pelaksanaan Dakwah yang Terkoordinir}

Dakwah adalah aktivitas intelektual, emotional dan spiritual yang harus dilakukan secara terencana agar dapat diterima oleh penerima dakwah. Dakwah melalui media membutuhkan perhatian lebih agar terlihat menarik dihadapan khalayak ramai. Dakwah melalui radio dan televisi adalah bentuk dakwah verbal baik secara audio maupun audio visual sehingga membutuhkan perencanaan yang matang. Kehebatan dakwah melalui radio dan televisi adalah jarak jangkauannya yang luas dan praktis sehingga sangat disayangkan jika tidak dilakukan secara terencana. Melakukan dakwah di radio dan televisi dengan perencanaan yang matang akan menghasilkan sebuah aktivitas dakwah yang terkoordinir.

Begitu pula yang dilakukan oleh PMD Kota Dumai dalam menyampaikan pesan dakwahnya melalui radio dan televisi. Sebelum melakukan dakwah di radio dan televisi PMD Kota Dumai telah melakukan langkah strategis, seperti kerjasama dengan radio dan televisi tertentu, pemetaan kondisi mad'u di media elektronik, persiapan da'i berbasis elektronik dan perumusan materi dakwah di media elektronik. Pada tahap berikutnya PMD Kota Dumai melakukan pelaksanaan dakwah di media elektronik yang terkoordinir. Pelaksanaan dakwah di radio Ar-Rahman 102,2 FM dilakukan

\footnotetext{
${ }^{26}$ Samsul Munir Amin,Ilmu Dakwah, hlm. 14.

${ }^{27}$ Kustadi Suhandang, Strategi Dakwah Penerapan Strategi Komunikasi dalam Dakwah, (Bandung: Remaja Rosdakarya, 2014), hlm. 105-106.
} 
dengan mengirimkan da'i-da'i PMD Kota Dumai ke radio sesuai jadwal yang diberikan oleh pihak radio tersebut. Dalam dakwahnya di radio da'i menyampaikan materi dakwah kurang lebih sepuluh menit, kemudian membuka forum tanya jawab kepada khalayak radio melalui petugas radio (penyiar).

Kegiatan dakwah ini dilakukan rutin setiap hari sesuai jadwal dari pihak radio. Adapun program-program dakwah radio tersebut adalah selamat pagi ar-Rahman, tausyiah kehidupan, kisah-kisah teladan, hikmah hadits pilihan dan sebagainya. Sedangkan dakwah melalui Dumai Vision dilakukan dengan cara pihak TV memberikan jadwal kepada PMD Kota Dumai, selanjutnya PMD Kota Dumai mengirimkan da'i-da'i yang sesuai keahliannya untuk melakukan dakwah di studio Dumai Vision. Kegiatan dakwah ini dilakukan ketika acara-acara keagamaan, seperti maulid nabi, isra' mi'raj, tahun baru hijriyah, kultum ramadhan menjelang berbuka puasa dan sebagainya.

Berbeda pula dengan pelaksanaan dakwah melalui Dumai Dokumentasi TV. Pelaksanaan dakwah melalui Dumai Dokumentasi TV dilakukan dengan adanya peliputan-peliputan terhadap kegiatan dakwah di PMD Kota Dumai, seperti tabligh akbar, isra' mi'raj, maulid nabi, pelatihanpelatihan dan sebagainya. Peliputanpeliputan tersebut selanjutnya disiarkan melalui TV Streaming Dumai Dokumentasi TV. Menurut penulis pelaksanaan dakwah di radio Ar-Rahman 102,2 FM yang dilakukan oleh PMD Kota Dumai telah sesuai dengan perencanaan yang telah disusun. Sedangkan dakwah melalui Dumai Vision yang dilakukan oleh PMD Kota Dumai juga berdasarkan perencanaan sebelumnya, akan tetapi perlu adanya peningkatan terhadap intensitas dakwahnya agar da'i lebih terbiasa dalam melakukan aktivitas dakwah di media elektronik. Tidak hanya dakwah melalui radio Ar-Rahman 102,2 FM dan Dumai Vision saja yang telah dilakukan sesuai dengan perencanaan, akan tetapi dakwah PMD Kota Dumaimelalui Dumai
Dokumentasi TV juga telah dilakukan berdasarkan kerjasama dan perencanaan sebelumnya.

Hal ini sesuai dengan pendapat Kustadi Suhandang yang mengatakan bahwa dalam melakukan strategi dakwah perlu adanya persiapan-persiapan, salah satunya adalah keputusan pilihan guna pelaksanaan yang tepat,terarah dalam pencapaian tujuan yang telah ditentukan dan prosedur pelaksanaan kegiatan yang akan dilakukan. ${ }^{28}$

Pelaksanaan dakwah melalui radio dan televisi di PMD Kota Dumai juga didukung oleh pemerintah kota Dumai dan beberapa perusahaan swasta seperti PT.Pertamina, PT. Cevron, BPJS Askes dan BPJS Jamsostek. Dukungan yang diberikan dalam bentuk moril dan materil seperti, dana, fasilitas, sarana prasarana, ruangan dan sebagainya. Menurut penulis dukungan-dukungan tersebut sangat menunjang keberhasilan dakwah melalui media elektronik di PMD Kota Dumai. Hal ini disebabkan bahwa aktivitas dakwah membutuhkan biaya yang besar sehingga dengan dukungan tersebut beban PMD Kota Dumai dapat terbantu. Selain itu, perusahaan-perusahaan swasta yang membantu aktivitas dakwah melalui media elektronik di PMD kota Dumai adalah perusahaan yang beroperasi di wilayah Dumai, sehingga jika perusahaan tersebut mendukung aktivitas dakwah di Kota Dumai.

Adapun pengawasan dakwah di radio dan televisi dilakukan langsung oleh Biro Pengembangan Dakwah PMD Kota Dumai selaku bidang yang menangani masalah dakwah di PMD Kota Dumai. Selanjutnya pengawasan diberikan kepada Kantor Urusan Agama, Kementerian Agama, Majelis Ulama Indonesia Kota Dumai dan Pemerintah Kota Dumai selaku pelindung dan penasehat di PMD Kota Dumai. Secara umum PMD Kota Dumai menyerahkan kepada masyarakat untuk memberikan kritik dan saran terhadap aktivitas dakwah di media elektronik.

Menurut penulis bahwa lembaga yang melakukan pengawasan tersebut adalah

${ }^{28}$ Kustadi Suhandang, Strategi Dakwah Penerapan Strategi Komunikasi dalam Dakwah, hlm. 105-106. 
pihak-pihak yang memang layak untuk mengawasi aktivitas dakwah di PMD Kota Dumai. Sedangkan masyarakat juga diberi ruang untuk menilai aktivitas dakwah di radio dan televisi. Semua itu dimaksudkan untuk perbaikan dakwah yang lebih baik dari waktu ke waktu di Kota Dumai, melalui PMD Kota Dumai. Hal ini sesuai pendapat Samsul Munir Amin bahwa pengawasan dilakukan untuk mengetahui kesulitankesulitan, kelemahan-kelemahan, hambatanhambatan kerja dakwah sebagai bahan perbaikan dan penyempurnaan aktivitas dakwah itu sendiri. ${ }^{29}$ Disamping itu dakwah memang membutuhkan pengawasan untuk memastikan dalam pelaksanaannya benarbenar sesuai kaidah agama Islam.

Melakukan aktivitas dakwah tidaklah semudah yang dibayangkan. Melakukan aktivitas mulia ini membutuhkan kesabaran dan keikhlasan yang mendalam. Begitu pula yang dihadapi oleh PMD Kota Dumai dalam dakwahnya melalui radio dan televisi. PMD Kota Dumai juga mempunyai hambatan dalam melakukan dakwah di radio dan televisi.

Hambatan yang dihadapi PMD Kota Dumai dalam melakukan dakwahnya di radio Ar-Rahman adalah pada kondisi masyarakat di Kota Dumai. Dewasa ini antusias masyarakat untuk mendengarkan radio Islam sangat minim sehingga ini menjadi tantangan bagi dakwah PMD Kota Dumai melalui radio. Sedangkan hambatan dakwah PMD Kota Dumai di Dumai Vision adalah tidak semua masyarakat Kota Dumai yang memakai jasa TV Kabel sehingga melalui Dumai Vision sangat terbatas pada kalangan pengguna TV Kabel (Dumai vision) saja. Berbeda dengan hambatan dakwah PMD Kota Dumai melalui Dumai Dokumentasi TV hanyalah persoalan kepekaaan masyarakat untuk membuka situs atau website Dumai Dokumentasi TV saja. Sebab Dumai Dokumentasi TV dapat diakses dimana saja dan kapan saja serta tidak terbatas pada Kota Dumai saja.

\section{4.}

Menanggapi penjelasan beberapa pengurus PMD Kota Dumai menurut penulis hambatan-hambatan yang dihadapi oleh PMD Kota Dumai pada dasarnya adalah hambatan-hambatan yang terdapat pada masyarakat itu sendiri bukan lembaga dakwahnya. Hendaknya PMD Kota Dumai harus mencari metode untuk membangkitkan animo masyarakat dalam mengakses radio dan televisi. Menurut penulis dengan mengonsep strategi-strategi dakwah baru di media elektronik yang kreatif dan inovatif sangat membantu tersampainya pesan-pesan dakwah yang akan disampaikan. Sebab salah satu kunci keberhasilan dakwah adalah adanya strategi yang tepat.

\section{Kesimpulan}

Berdasarkan Pembahasan tentang Strategi Dakwah berbasis Media Elektronik di PMD Kota Dumai, dapat disimpulkan bahwa Persatuan Mubaligh Dumai telah melakukan strategi dakwah berbasis media elektronik yaitu melalui radio Ar-Rahman 102,2 FM, Dumai vision dan Dumai Dokumentasi TV dengan efektif,tetapi pelaksanaannya perlu dioptimalisasikan lagi.

Adapun strategi dakwah berbasis media elektronik yang dilakukannya, yaitu: Pertama, melakukan kerjasama dengan lembaga terkait seperti radio Ar-rahman 102,2 FM, Dumai Dokumentasi TV dan Dumai Vision. Kerjasama tersebut dalam bentuk siaran langsung atau live dan peliputan-peliputan. Kedua, melakukan pemetaan kondisi mad'u di radio Ar-rahman 102,2 FM, Dumai Dokumentasi TV dan Dumai Vision. Ketiga, mempersiapkan da'i berbasis media elektronik melalui workshop, pelatihan kader da'i, muzakarah, sertifikasi da'i dan sebagainya. Keempat, perumusan materi dakwah di media elektronik melalui tim yang ditunjuk oleh Pengurus harian PMD Kota Dumai dan dibantu oleh para pakar dakwah. Kelima, melaksanakan dakwah di media elektronik secara terkoordinir.

\section{Bibliografi}

Amin, Samsul Munir. Ilmu dakwah, (Jakarta:Amzah, 2013). 
Ardianto, Elvinaro dkk.Komunikasi Massa edisi Revisi, (Bandung: Simbiosa Rekatama Media, 2007).

Arifin, Anwar.Dakwah Kontemporer: Sebuah Studi Komunikasi, (Yogyakarta: Graha Ilmu, 2011).

Arifin, Muhammad. Dakwah Multi Media:Terobosan baru Bagi Para Da'i, (Surabaya: Graha Ilmu Mulia, 2006).

Effendi, dikutip dari Rafi' Udin, Prinsip dan Strategi Dakwah, (Bandung: Pustaka Media, 1992).

Hartono, Toni dkk. Komunikasi Dakwah, (Pekanbaru: Yayasan Pusaka Riau, 2011).

Hasil observasi dengan beberapa masyarakat Kota Dumai pada tanggal 15 Mei 2016, Pukul 16.00 WIB.

Ilaihi, Wahyu. Komunikasi Dakwah, (Bandung: Remaja Rosdakarya, 2010).

Kementerian Agama RI, Al-Qur'an Tajwid dan Terjemah, (Bandung: Syaamil Quran, 2010).

Muhtadi, Asep Saeful. Komunikasi Dakwah Teori, Pendekatan, dan Aplikasi, (Bandung:Simbiosa Rekatama Media, 2012).

Munir, M dan Wahyu Ilaihi. Manajemen Dakwah, (Jakarta:Kencana, 2015).

Nilasari, Senja Nilasari. Manajemen Strategi itu Gampang, (Jakarta: Dunia Cerdas, 2014).

Prawirosentono, Suyadidan Dewi Primasari.Manajemen Stratejik dan Pengambilan Keputusan Korporasi, (Jakarta: Bumi Aksara, 2014).

Suhandang, Kustadi. Strategi Dakwah Penerapan Strategi Komunikasi dalam Dakwah, (Bandung:Remaja Rosdakarya, 2014).

Syukir, Asmuni. Strategi Dakwah Islam, (Surabaya: Usaha Nasional, 1983).

Tamburaka, Apriadi. Literasi Media, (Jakarta:Rajawali Pers, 2013).

Tohirin. Metodologi Penelitian Kualitatif, (Jakarta: PT.Raja Grafindo Persada, 2012).

\section{Daftar Jurnal :}

Ahmad Atabik, "Prospek Dakwah melalui Media Televisi", Jurnal Komunikasi Penyiaran Islam Vol.1, No.2 (Juli-Desember 2013).

Eva Maghfiroh, "Komunikasi Dakwah: Dakwah Interaktif melalui Media Komunikasi”, Jurnal Dakwah dan Komunikasi Islam Vol.2, No.1 (Februari 2016) 